\title{
5.3 Колізії розвитку української ліберальної думки першої половини XIX століття
}

Розглядаючи особливості зародження ліберальної доктрини в Україні існує думка про те, що у нас немає підстав шукати витоків українського лібералізму до початку XIX ст. Більшість дослідників погодиться з таким висновком тільки в тому випадку, коли йтиме мова про імперську суспільно-політичну думку, носієм якої зазвичай було російське дворянство. Стосовно ж витоків українського лібералізму, то ті ж самі дослідники намагаються показати його премодерний характер. Н. Гедікова, розглядаючи становлення ліберальної доктрини в Україні, стверджує, що «це тисячолітній процес, який з моменту свого зародження, становлення і розвитку, не дивлячись на всілякі історичні умови й багатогранну систему поглядів, завжди носив безперервний, поступальний і еволюційний характер. Кожен новий його етап - продовжує свою думку дослідниця - спирався на попередні досягнення конкретної епохи, збагачувався i доповнювався, як власними накопиченими традиціями, так i досягненнями світової ліберальної думки» [146, с. 83]. Н. Гедікова також зазначає, що як «самостійне науково-теоретичне вчення вона [ліберальна думка - уточ. автор] починає оформлюватися з середини XIX століття, набуваючи своєї істинної значимості на межі XIX-XX ст.» [146, с. 83].

Незважаючи на раціональність останнього зауваження Н. Гедікової, говорити про традицію ліберальної думки в Україні, що сягає тисячі років, наразі, немає жодних підстав. Українське суспільство розвивалося у контексті загальних тенденцій розвитку європейського соціуму, тому, до початку модерної епохи говорити про зародження ліберальної традиції немає сенсу. Якщо взяти до

уваги позицію Д. Чижевського щодо своєрідності української ментальності, невіддільною рисою якої $є$ «індивідуалізм та стремління до «свободи» в різних розуміннях цього слова» [163], можна говорити про рецепції лібералізму як духовної настанови суспільства. Мислитель зосереджує свою увагу на тому, що «індивідуалізм може вести до самоізолювання, до конфлікту з усім та усіма, до 
розкладу усякої життьової форми; разом з тим індивідуалізм може вести й веде у деяких випадках до глибоко-позитивних форм творчості й активності. Поруч 3 цими двома рисами, стоїть третя - неспокій і рухливість, більш психічні, ніж зовнішні, неспокій і рухливість, що зв’язані із певним «артистизмом» натури, зі стремлінням до переходу в усе нові й нові форми, але разом 3 тим 3 індивідуалізмом, що не хоче мати ніяких сталих, міцних основ поза межами індивідуума, а не може відшукати їх в ньому самім; з цією рисою зв'язані і дуже позитивні риси характеру, як здібність до прийняття нового, тенденції до психічної еволюції, але і максимально негативні сторінки української історії «шатость», тенденція до взаємної боротьби, до руйнування власних і чужих життьових форм, усі жорстокі та криваві сторінки української історії» [163].

Попри визнання безсумнівного авторитету Д. Чижевського, його твердження $є$ не цілком правомірними. Зокрема, з огляду на високий рівень релігійності населення, що, як зауважував А. Антонович [144] та, особливо, I. Огієнко [157], проявлялася у вигляді двовір'я. Сумнівними є зауваження Д. Чижевського про те, що 3 українським індивідуалізмом була пов'язана здібність украӥнців до прийняття нового. Такий висновок $є$ доволі проблематичним, особливо у випадках, коли лібералізм розглядається не як політична доктрина, а як світоглядна настанова певної спільноти. Значна частина українського населення, яка ідентифікувала себе українцями, до початку ХХ ст. проживала у сільській місцевості, а відтак зберегла притаманний міфологічній свідомості біполярний світогляд.

Ця ситуація істотно нівелювалася на західноукраїнських землях завдяки тому, що освічене уніатське духовенство вело схожий до сільського простонароддя спосіб життя (подружнє життя, заняття землеробством). Це формувало відчуття нерозривної єдності між простим народом і духовенством. Неможливо оминути того факту, що це дало можливість останньому транслювати в це консервативне середовище нові світоглядні принципи та цінності, які були притаманні для цього періоду. В особливий спосіб ця тенденція проявилася у період після реформ Марії-Терези та Йосифа II, у 
кінцевому результаті яких уніатське духовенство зрівнялося із католицьким у правах та освіті [156, с. 414].

На території України, яка була підконтрольною Російській імперії ситуація істотно відрізнялася від тієї яка склалася на західноукраїнським землях, де у підсумку історико-культурного розвитку та політичної приналежності цінності та норми західноєвропейського світу хоча б частково транслювалися у середовище народних мас. Після приєднання Київського патріархату до Московської митрополії у 1685-1686 pp., завдяки європейській освіті вільнодумства усі елементи притаманного українському духовенству поступово придушувалися. Більше того, за словами Ю. Романенко та О. Донченко, східнохристиянська релігійна традиція характеризується виразним консерватизмом, який постав закономірним результатом пануючих тут архетипів вічного учня та вічного повернення [148]. У соціокультурному просторі ці архетипи проявлялися не тільки у глибокому консерватизмі, а й ворожості до усього нового, що й дало можливість С. Томашівському говорити про те, що вибір Володимира свого часу був трагічною помилкою, яка призвела до застою української культури та прирекла iї на безплідність та замкнутість [155, с. 7].

Експлікація І. Лисяка-Рудницьким поглядів С. Томашівського постає радше авторською інтерпретацією, ніж відтворенням світоглядних інтенцій творчості С. Томашівського, який вів мову передусім про необхідність подальшого розвою церковної унії в Україні, бо вона більше відповідає ментальності українського народу. Це чітко проявляється у ментальній інтенції українського індивідуалізму православного населення. На противагу уніатству, яке мало організаційний зв'язок із західноєвропейським світом, православне духовенство після інкорпорації Київського патріархату до складу Московської митрополії, втратило будь-яку можливість для вільнодумства. Це, у єдності притаманною сільському населенню біполярною міфологічною моделлю світу, робило українське простонароддя нечутливим до змін і нововведень. Як доводить Н. Кривда, саме дана обставина мала вагоме значення для збереження в децентралізованому вигляді самобутньої української культури [151], яка, 
зазвичай, була представлена властивим премодерній культурі колективним «Ми», що есплікувалося, як родина, як громада, як етнографічний регіон, однак завжди у протиставленні до «Вони». Власне саме у підсумку своєрідності українського двовір'я, який виявлявся у своєрідній обрядовій практиці, як стверджує Н. Кривда, сформувався етнографічний фундамент для формування колективного етнографічного «Ми», свідомість якого, як свідчить інтелектуальний дискурс кінця XVIII - початку XIX ст., утверджувалася під впливом антиукраїнської політики Російського уряду. Дивлячись, як традиційні життєві форми поступово зникають, етнічно свідомі представники козацької шляхти охоче збирали пам'ятки старовини - давні літописи, документи та архівні матеріали з метою зберегти на їх тлі минулу малоросійську велич [152, c.259].

Вплив біполярної міфологічної моделі світу, передусім, серед представників української шляхти особливо виразно проявився тоді, «коли російський уряд, починаючи з самої цариці Катерини II, докладав усіх зусиль для того аби не тільки назва, а і сама пам'ять про часи гетьманщини зникла, i щоб раз назавжди викорінився погляд, ніби українці - якийсь «окремий народ од москалів» [149]. Між тим, саме в цей час починають 3'являтися праці в яких обгрунтовувалася тяглість української політичної свідомості, що виразно проявилося у «Краткой летописи Малыя Россіи с 1506 по 1776 год» (В. Рубана), «Записках о Малороссіи» (Я. Марковича), «Історії Русів» (1829 р.) тощо. Як слушно наголошує О.Салтовський усі представники тогочасного інтелектуального дискурсу «стояли на позиціях консерватизму, тобто на позиціях визнання особливих цінностей традиційного ладу, традиційних форм життя, діяльності суспільства і держави. Консерватизм став їхньою ідеологічною платформою в боротьбі за збереження національних і станових привілеїв» [160].

Розвиток ліберальної думки в Україні сповільнювало й те, що становлення новітньої української еліти, що формувалася в університетах, відбувалося під ідейним впливом німецької філософії, а саме вченням Й.Шада. Він був незалежним дослідником філософії І. Канта і Й. Фіхте та виражав зацікавлення 
та повагу до свободи та гідності людини. Як зазначає М. Семчишин, вчений у цьому плані був співзвучний з традицією української інтелектуальної думки й, передусім, філософією Г. Сковороди. Й. Шад, на відміну від Г. Сковороди, у творчості якого ідея свободи не набула чітко раціоналізованої форми, був яскравим противником «всякого насильства над свободою» [161, с. 221].

Ідейна доктрина Й. Шада попри рецепції лібералізму у його філософії не одразу і не повною мірою визначила розвиток української соціогуманітарної думки. Це було зумовлено тим, що на початку XIX ст. українці були свідомі не тільки власної етнічної ідентичності, а й того, що залучення до передової європейської цивілізації вимагає культурної трансформації. «Поступово втягуючись у чужу їм цивілізацію... У своїх зусиллях утвердити себе як рівних на теренах не їхнього витвору цивілізації вони, мусили, так би мовити, вибудувати себе заново, створювати власні національні ідентичності. Нема сумніву в тому, - зауважує Дж. Пламенац, - що коли націоналізм вперше почав серед них вкорінюватися, то вони вже мали певне почуття ідентичності чи окремішності. Але було також усвідомлення того, що вміння, ідеї та звичаї, набуті від їхніх предків, $є$ неадекватними з огляду на необхідність піднятися до рівня більш передових народів, згідно зі стандартами цивілізації» $[158$, с. 488489].

Поширення соціальної теорії, й зокрема, теорії нації Й. Шада, а 3 ними запозиченої від німецьких романтиків цікавості до етнографії та фольклору, певним чином було зумовлене намаганнями віднайти спільні риси із передовими народами світу та звільнитися від російського панування i, особливо, винародовлення. Українська інтелігенція усвідомлювала те, що долучитися до цивілізації, яка є для них абсолютно чужою, можна тільки шляхом прийняття відповідної їм культури та мови, що обов'язково призведе, в кінцевому випадку, до знищення тих якостей та характеристик, які визначають їх власну народну культурну самобутність.

Вагоме значення, на думку I. Лисяка-Рудницького, для сприйняття національних ідей сформованих в межах німецької філософської думки й, 
передусім, творчості Й. Гедера, В. Гумбольдта та Й. Фіхте мало те, що стара «українська суто державницька національна свідомість ставала в умовах першої половини XIX ст. практично неплідною, ставила Україну перед примарою національної смерті. Висунення на перший план «мужицького» етнографізму замість панського політичного історизму, демократичного народництва замість аристократичного державництва під знаком «прав і привілеїв» було в той час єдиним порятунком для національної ідеї, єдиним можливим виходом 3 ідеологічно сліпого кута. Відкривало широкі шляхи для культурної творчості, шлях від вивчення життя мас до їх усвідомлення («просвітянство»), для всього того, що творило нові підстави майбутнього відродження державної ідеї» [154, с. 207]. Іншими словами, єдиним виходом для того аби зберегти українську ідентичність стало опертя політичних і культурних прагнень інтелігенції на народну масу. Звернення української інтелігенції до народу було закономірним ще й тому, що побудувати «нову Україну можна було лише на місці селянського народу, бо масові кадри інтелігенції можна було вербувати лише у верствах, наближених до селян: сільських священиків, дрібних землевласників, міщан, заможних селян козацького походження тощо» [147]. Натоміть українські землевласники, i, тим паче, підприємці, були великою мірою денаціоналізовані, а відтак їх цікавість Україною обмежувалася тільки економічною чи політичною сферами.

У суспільній свідомості українців, досить швидко поширилася думка про те, що для народу дуже важливим є відстоювати свою культурну ідентичність, «бути собі вірним», «наслідувати свій природний дух» і не дозволяти іноземним звичаям себе переваблювати [158, с. 490].

Розкриваючи історію ліберальної думки в Україні, Н. Гедікова звертає увагу на те, що в основу українського лібералізму «були покладені традиції, створені попереднім поколінням представників українського ліберального толку, зокрема ідеологами першої половини XIX століття (Т. Шевченком, М. Костомаровим, Г. Андрузьким, П. Кулішом та ін.), що явилися тією опозиційною силою, яка змогла протистояти режиму Миколи I (1822-1855)» [146, с. 84]. Подібні думки 
зустрічаються й у творах І. Лисяка-Рудницького, який в ідеології КирилоМефодіївського товариства бачить органічне поєднання трьох традицій: романтичного етнографізму й культурництва харків'ян; традиційного козацького державництва та модерних західноєвропейських ідей лібералізму та демократизму [154, с. 208]. Мислитель стверджує, що перша модерна українська політична програма взяла за основу ідею вільної української республіки.

Ïї грунтований аналіз дає можливість чітко визначити вплив західноєвропейського лібералізму на становлення української суспільнополітичної думки першої половини XIX ст. Аналізуючи колізії українського буття в історичній ретроспективі, М. Костомаров неодноразово звертається до необхідності максимально повної реалізації свободи. На користь висновку, щодо відсутності ліберальних тенденцій у творчості мислителя, слугує, як мінімум, запропонований ним аналіз змісту свободи в античній Греції. «Греки, - пише М. Костомаров, - не дізнались правдивої свободи, бо хоч одріклись царей земних, та не знали царя небесного і вимишляли собі богів; і так царей у їх не було, а боги були, тим вони вполовину стали такими, якими були б, коли б у них не було богів і знали б небесного бога. Бо хоч вони багато говорили про свободу, а свободні були не всі, а тільки одна частка народа, прочі ж були невольниками; і так, царів не було, а панство було: а то все рівно, якби у їх було багато царків» [162].

У запропонованому уривку, М. Костомаров визнає наявність свободи у давніх греків. Такий висновок, можна вважати цілком достовірним, тим паче, коли мова йде про свободу, як ключову цінність ліберальної доктрини. Немає жодних підстав виводити ії з античних часів, і тим паче говорити про наявність індивідуальної свободи у давніх греків. Схоже тлумачить М. Костомаров зміст свободи й тоді, коли говорить про українців. Так, наприклад, пропонуючи програму майбутньої слов'янської федерації, яка могла б цілком відповідати ліберальним принципам, М. Костомаров пише: «голос іiі [України - уточ. автор], голос, що звал всю Слов'янщину на свободу і братерство, розійшовся по світу 
слов'янському. I одізвався він, той голос України, в Польщі, коли 3 мая постановили поляки, щоб не було панів і всі були б рівні в Речі Посполитій; а того хотіла Україна за 120 літ до того» [162].

Розгляд свободи у єдності з рівністю, який пропонує М. Костомаров дає можливість стверджувати, що погляди мислителя мали республіканськодемократичне, а не ліберальне забарвлення. Дане зауваження цілком підтверджує специфіка тлумаченням мислителем проблеми рівності. В цьому контексті, особливу увагу привертає наступне твердження мислителя: «А сьому ще гірша неправда, бутсім установлено од бога, щоб одні пановали й багатились, а другі були у неволі й нищі, бо не було б сього, скоро б поприймали щире Євангеліє; пани повинні свободити своїх невольників і зробитись їм братами, а багаті повинні наділяти нищих, й нищі стали б также багаті; якби була на світі любов християнська в серцях, то так було б, бо хто любить к[о]го, той хоче, щоб тому було также хороше, як і йому» [162]. Наведене зауваження чітко демострує прихильність М. Костомарова до теорії соціальної рівності, в межах якої людина отримує громадські блага не стільки, скільки сама заробляє, а рівно стільки, скільки їх мають інші члени іiі групи. В межах такої концепції, розподіл соціальних благ набуває зрівняльного характеру, а значення людини в суспільстві визначається не у відповідності до її особистого трудового внеску, а відповідно до загального соціального статусу тієї соціальної групи, яку вона представляє.

Ліберали (А. Сміт, Б. Констанс, А. де Токвіль та ін.) розглядали рівність, крізь призму рівноправності, яка встановлюється за допомогою закону i спрямована гарантувати кожній людині індивідуальні права та свободи. Вони виступали за широкий розподіл праці, ринкову свободу і підприємницьку ініціативу, розуміючи найважливішу роль економіки в суспільному житті людей. Інакше кажучи, ліберали, розглядаючи проблему рівності, зосереджувалися не на рівності кінцевого результату, а на можливості ïi реалізації. Їх цікавило забезпечення цієї можливості для кожної людини отримувати відповідно до власних здібностей, а не результат. Такий підхід, без жодного сумніву, у 
реальному житті призводить до нерівності, яка стає закономірним результатом того, що люди нерівні у своїх трудових параметрах (фізична сила, розумові здібності, освіта, накопичення тощо).

Проблема рівноправності у творчості М. Костомарова мала непересічне значення, адже саме завдяки їй можна було побудувати справедливу слов'янську федерацію. У «Книзі буття українського народу» мислитель обгрунтовує християнський характер Слов’янщини, яка буде вибудована на основі любові до Ісуса Христа. Від самого початку утвердження християнства та розвитку перших християнських громад 3 притаманною їм рівністю, не було місця для індивідуальної свободи. Перші християнські громади формувалися керуючись словами Христа «Бо де двоє чи троє в Ім'я Моє зібрані, там Я серед них» (Від Матвія 18:20), зафіксованими у Свангеліє від Матвія і були єдино можливим способом долучитися до християнської істини, яка відкривалася людині у живій традиції співжиття у християнській громаді [150, с. 61]. Ситуація докорінно не змінилася і згодом, так як спільнота об'єднана навколо релігійного ядра, i, особливо, православ’я, не має простору індивідуальної свободи, оскільки в такій спільноті людина визначається крізь призму колективного «Ми». Саме такий підхід спостерігається у М. Костомарова, який веде мову не про звільнення від соціального поневолення кожної людини, скільки про деяке колективне «Ми» в даному конкретному випадку, 3 одного боку, слов'яни, тобто люди, що пов'язані своїм історичним походженням, а $з$ іншого - українці, чехи, поляки тощо, тобто ті, що мають власну етнічну ідентичність.

М. Костомаров, говорячи про «свободу та рівність», що сформувалися на тлі дотримання «закону божого», і проявлялися в тому, що українці, як ніхто в світі моляться богу, у «муж любив жону, а діти своїх родителей» [162] не брав до уваги архаїчний характер життя українського простонароддя $\mathrm{i}$, особливо, його двоєвірного характеру. Адже, первісна родова спільнота, формування «Ми», що представлені як domus, тобто сім’я, родина, передбачало виділення Космосу iз первинного Хаосу, тобто встановлення природного порядку, який би забезпечив безперервне життя родової спільноти. Кожна людина залежно від віку та статі, в 
межах такого Космосу, посідала своє власне місце і виконувала покладені на неї обов’язки. I те, і інше, було результатом встановленого «од віку» порядку, й не передбачало вільного вибору людини. Глибока взаємоповага в українській родині, на якій акцентували увагу багато українських мислителів, є результатом двоєвірного характеру життя українського простонароддя, яке намагалося утримати всесвітній порядок проявляючи зовнішньо соціальні функції.

Отже, наразі немає жодних підстав говорити про рецепції лібералізму у творчості М. Костомарова, який переймався свободою колективу, а не окремої особистості.

П. Куліш розглядає індивіда через його конотацію 3 історичною долею спільноти. Експлікація цієї ідеї здійснюється за допомогою вчення про «народний дух», який у творчій спадщині П. Куліша, тлумачиться як індивідуальний вияв, «трансцендентної субстанційної сили; він становить первень i сутність спільноти, праоснову народного буття i втілює себе символічно в предковічних цінностях народу, закодованих у його мові. Втрачаючи iị, народ губить ціннісні орієнтири, визначальний для себе модус світовідношення, а отже можливості «розвитку його моральних сил». Індивід, обезмовлюючись, позбавляє себе єдиного, даного Богом, способу залучення до духовно-культурних традицій народу і нікчемніє» [153].

Запропонована І. Лисим характеристика творчої спадщини П. Куліша не потребує жодних уточнень чи характеристик, адже в ній немає жодного натяку на ліберальні принципи. Проте, відкритим залишається питання щодо того, чому все таки провідні українські дослідники, в тому числі й Н. Гедікова, вбачають у поглядах згаданих дослідників рецепції лібералізму.

Відповідь на це питання отримуємо звернувшись до праць Ю. Габермаса, й, передусім, до здійсненого ним розрізнення активного стану громадянства. 3 одного боку, мислитель виокремлює ліберальну традицію природного права, яка бере свій початок від Дж. Локка й розвиває індивідуалістичноінструменталістське розуміння ролі громадянина, а з іншого - республіканську традицію, яка бере свій початок від вчення про державу Аристотеля, де 
формується комунікаційно-етичне тлумачення ролі громадянина [145, с. 348]. В першому випадку «громадянство окреслюється за зразком організаційного членства, яке встановлює правове становище людини, в іншому випадку належністю до самовизначеної етично-культурної спільноти» [145, с. 348].

Виокремлення двох політичних традицій, дає можливість Ю. Габермасу, показати їх вплив на специфіку політичної діяльності. 3 позиції першого, тобто ліберального підходу, «окрема людина є зовнішньою стосовно держави, у відтворення якої вона робить певний внесок, скажімо, у вигляді виборчого голосу чи сплати податку, для того, щоб отримати натомість успішне функціонування структури [держави]. Відповідно до іншого тлумачення, громадяни об’єднуються в політичну спільність як частини цілого настільки, що можуть витворити свою особисту і соціальну ідентичність лише в просторі загальних процесів і визнаних політичних інституцій» [145, с. 348$]$.

Громадяни мало чим відрізняються від приватних осіб, які частіше за все віддають перевагу своїм неполітичним інтересам в межах ліберальної політичної традиції. В межах республіканської традиції громадянство реалізується в процесі колективного самовизначення, оскільки, акцентуючи увагу на приватній користі, немає можливості досягти політичної автономності. В межах республіканської традиції, «інституції свободи, забезпечені конституційно-правовим чином, є цінністю лише настільки, наскільки звикле до політичної влади, привчене до неї населення бачить в їхньому існуванні перспективу самовизначення для себе» $[145$, c. 348$]$.

Беручи до уваги позицію Ю. Габермаса, можна стверджувати, що повноцінне громадянське суспільство, за умов панування республіканськодемократичної традиції, яку започаткували Кирило-Мефодіївці, зокрема, та народники загалом, побудувати практично неможливо, так як людина самовизначається і проявляє свободу тільки в певному колективному просторі, який, завдяки деяким культурним ознакам, визнається своїм. Очевидно, що саме з цієї причини, тривалий час в українській інтелектуальній думці ліберальні ідеї не знаходили грунту для свого розвитку. 
Попри те, що Кирило-Мефодіївці та народники загалом мали дуже мало спільних ідей із західноєвропейською ліберальною доктриною, Н. Гедікова вважає, що «ліберальний рух в Україні (у цілісній територіальній ії єдності), який став основною передумовою історичного розвитку, розвивався в умовах, стіснених між двома імперськими режимами, з обмеженою соціальною базою, яка не мала гідної підтримки ні з боку уряду, ні з боку народних мас, тому «агато положень класичного лібералізму були тут інтерпретовані відповідно до місцевих умов» [146, с. 84]. Лібералізм є космополітичною ідеологією освічених представників буржуазії, яка бореться спочатку за власні політичні права, а потім проти репресивності державного управління. Натомість українське соціальне життя першої половини XIX ст., визначалося кріпосною залежністю, яку можна назвати різновидом премодерних соціальних зв'язків 3 чітко вираженою ієрархічною структурою суспільства. Відповідно, суспільно-політична думка цього періоду зосередила свою увагу на формуванні народного «Ми», або ж «загальної волі» у визначенні Ж.-Ж. Руссо.

Перебільшеним здається і зауваження Н. Гедікової щодо того, що «з підготовкою і відміною кріпосного права, проведенням інших прогресивних реформ, лібералізм набув більш оформленого характеру, посилював свої ідейні позиції, став політичною течією, з якою вимушені були рахуватися» [146, с. 84]. Дослідниця зазначає, що головними ідеями прихильників ліберальної доктрини стали: політичні і громадянські свободи, культурно-просвітницька робота серед народу і ознайомлення його з європейською культурою; боротьба з імперською політикою царизму; розподіл влади; непорушність приватної власності; українське національне відродження і територіальна єдність України, іiі самостійність; створення громадянського суспільства і такого державного порядку, за якого усі суспільні інститути діяли би в інтересах особистості й переважної більшості тощо.

Більшість 3 виокремлених Н. Гедіковою характеристик українського лібералізму першої половини XIX ст., не мають нічого спільного $з$ ідеями класичного лібералізму. Головною суперечністю в цьому контексті $\epsilon$ 
національний вимір суспільно-політичної думки першої половини XIX ст. Лібералізм - це космополітична доктрина, яка $є$ необмеженою національними рамками. Немає жодних підстав розглядати зв'язок ліберальної доктрини із демократичними прагненнями чи характерним для українського руху за громадянські права широких народних мас чи територіальну єдність українців. Ці риси є співзвучними з ідеями Ж.-Ж. Руссо й, особливо, концептами загальної волі та суверенітету народу [159], між тим мають небагато спільного 3 ліберальною ідеєю свободи, яка, як зазначає А. де Токвіль, породжує тиранію спільноти, яка завжди намагається встановити дійсну рівність. Іншими словами, колективне самовизначення веде до добровільного поневолення індивіда, який приєднавшись до колективного «Ми» втрачає частину свободи. 